\title{
ENZYMES AND TRYPSIN INHIBITOR IN THE RETE TESTIS FLUID OF RAMS AND BOARS
}

\author{
J. SUOMINEN* AND B. P. SETCHELL \\ Department of Biochemistry, A.R.C. Institute of Animal Physiology, \\ Babraham, Cambridge
}

(Received 1st Fuly 1971, accepted 13th September 1971)

\begin{abstract}
Summary. Compared with blood plasma, rete testis fluid (RTF) from rams was found to contain a higher concentration per unit volume of the enzymes that occur in the sperm acrosome and in the kinoplasmic droplet, but the levels of these enzymes could be reduced by high-speed centrifugation. Other enzymes present in blood plasma were also found in RTF but at a lower concentration per unit volume. Because of the low concentration of protein in RTF, however, the activity of most of these enzymes per unit weight of protein was higher in RTF than in blood plasma. The concentrations of these enzymes and the total protein concentrations were only slightly reduced by high speed centrifugation. There was no appreciable concentration of the X-isoenzyme of lactic dehydrogenase in RTF and the activity of most enzymes per unit weight of protein was less in RTF than in the testis.

Epididymal plasma and RTF from rams and boars were found to contain appreciable concentrations of an inhibitor of trypsin and the activity of the inhibitor per unit weight of protein was comparable with the activity in seminal plasma.
\end{abstract}

\section{INTRODUCTION}

Fluid collected from the rete testis of rams has been shown to contain only a fraction of the protein found in blood plasma (Setchell, 1970). The protein which is present is mainly albumin but there are suggestions that the fluid may contain some specific proteins (Johnson \& Setchell, 1968). In an attempt to clarify this problem, the activities of a number of enzymes have been measured in rete testis fluid (RTF) and blood plasma. The enzymes chosen were either specific to the testis, normally present in blood plasma or lysosomal enzymes normally present in the acrosome of the spermatozoa and the kinoplasmic droplet.

An inhibitor of proteolytic enzymes such as trypsin has been found in seminal plasma and it is thought that removal or dilution of this enzyme may be important in the processes of capacitation and the acrosome reaction (see Bedford, 1970). Such an enzyme inhibitor may also protect the spermatozoa

* Present address: Department of Anatomy, University of Turku, Turku, Finland. 
during storage in the epididymis and therefore this inhibitor has been sought in rete testis fluid and epididymal seminal plasma.

\section{MATERIALS AND METHODS}

Six Clun Forest or Clun Forest-Finnish Landrace rams, 2 to 5 years old and weighing between 52 and $70 \mathrm{~kg}$, and two Large White boars, 14 months old and weighing about 250 and $270 \mathrm{~kg}$, were used. The rams were housed in metabolism cages in a room kept at $15^{\circ} \mathrm{C}$; they were fed $1000 \mathrm{~g}$ pasture hay and $200 \mathrm{~g}$ sheep nuts daily. The boars were kept indoors and fed $2500 \mathrm{~g}$ pig breeder nuts (Barkers \& Lee-Smith) daily. Rete testis cannulae were implanted by the technique described by Voglmayr, Scott, Setchell \& Waites (1967), except that a T-shaped cannula was used with the stem of the $\mathrm{T}$ in the rete. Filtered air (Millipore SXGS $0.22 \mu \mathrm{m}$ ) was drawn across the top of the T so that the fluid was quickly carried away from the animal to a container kept in crushed ice. Epididymal fluid was collected under fluothane (Halothane I.C.I.) anaesthesia through a PVC cannula in the ductus deferens.

The boars were anaesthetized with Immobolon (Reckitt \& Coleman, Hull) or pentobarbitone sodium and maintained with fluothane given through a closed circuit apparatus. Collections of rete testis fluid and epididymal contents were made by techniques similar to those used in the rams. Fluids from the seminal vesicles and Cowper's glands were collected at post mortem. Spermatozoa were removed as soon as possible from the fluids by centrifugation at $3000 \mathrm{~g}$ for $20 \mathrm{~min}$ and the fluids were stored at $-20^{\circ} \mathrm{C}$ until assayed. With four samples of rete testis fluid, a portion was subjected to a second centrifugation at $100,000 \mathrm{~g}$ for $\mathrm{I} \mathrm{hr}$ at $4^{\circ} \mathrm{C}$ to remove any cellular débris.

A piece of ram testis was obtained during operation and was homogenized in cold $0 \cdot 15 \mathrm{M}-\mathrm{KCl}$ with a Potter-Elvehjem homogenizer. The homogenate was frozen and thawed three times and cellular débris was removed by centrifugation at $3000 \mathrm{~g}$ for $20 \mathrm{~min}$. Finally, the homogenate was centrifuged at $70,000 \mathrm{~g}$ for $30 \mathrm{~min}$ and the supernatant, referred to as testis extract (T), used for enzyme assays.

\section{Determination of enzyme activities}

The samples of blood plasma, rete testis fluid and testis extract were divided into small portions, and one portion was thawed and diluted with $0.9 \% \mathrm{NaCl}$, if necessary, for each analysis. All enzyme assays were done in duplicate at $+37^{\circ} \mathrm{C}$.

The activities of glutamate dehydrogenase (GLDH; EC 1.4.1.2), glutamicoxaloacetic transaminase (GOT; EC 2.6.1.1), glutamic-pyruvic transaminase (GPT; EC 2.6.1.2), glucose-6-phosphate dehydrogenase (G-6-PDH; EC 1.1.1.49), isocitrate dehydrogenase (ICDH; EG 1.1.1.42), lactate dehydrogenase (LDH; EC 1.1.1.27), malate dehydrogenase (MDH; EC 1.1.1.37), pyruvate kinase (PK; EC 2.7.1.40) and sorbitol dehydrogenase (SDH; EC 1.1.1.14) were measured according to Boehringer's 'Test Handbook' and all substrates and reagents for these enzyme assays were 'test kits' purchased from Boehringer (Mannheim, Germany). 


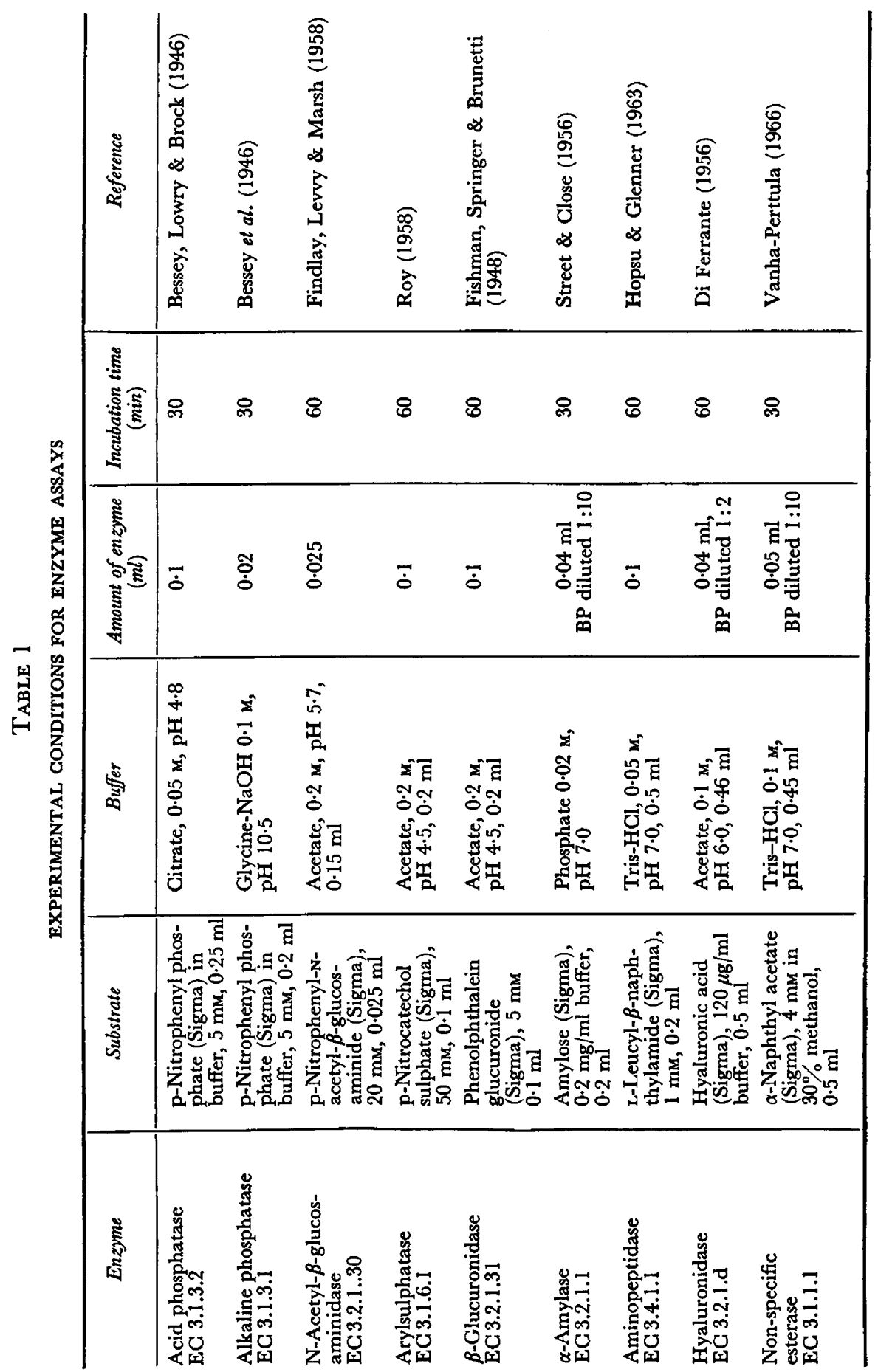


The methods and experimental conditions for other enzyme assays are given in Table 1.

\section{Estimation of trypsin inhibitor}

This determination was based on the method described by Fritz, Trautschold, Haendle \& Werle (1968). Purified trypsin (from bovine pancreas; Boehringer, Mannheim, Germany) was dissolved into $1 \mathrm{~mm}-\mathrm{HCl}-10 \mathrm{~mm}-$ $\mathrm{CaCl}_{2}$ solution $(1 \mathrm{mg} / 75 \mathrm{ml}$ ) and $\mathrm{N}$-benzoyl-DL-arginine-p-nitroanilide(BAPA; Sigma) was used as substrate (1 mm solution in distilled water). The

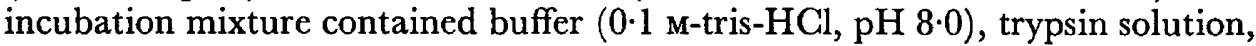
sample and substrate solution, $0.2 \mathrm{ml}$ of each. Before the substrate was added, the tubes were preincubated at $+37^{\circ} \mathrm{C}$ for $15 \mathrm{~min}$. The actual incubation lasted for $60 \mathrm{~min}$ and the reaction was stopped by adding $0.4 \mathrm{ml}$ sodium acetate-HCl buffer $(1.0 \mathrm{~m}, \mathrm{pH} 4 \cdot 2)$. Optical densities were measured at a wavelength of $383 \mathrm{~nm}$. The results are given in inhibitor milliunits (1 inhibitor unit is the amount of inhibitor which reduces the hydrolysis of substrate by $1 \mu \mathrm{mol} / \mathrm{min}$ at $+37^{\circ} \mathrm{C}$ ).

\section{Prolein content}

Protein was determined according to the method of Lowry, Rosebrough, Farr \& Randall (1951) using a standard curve prepared with bovine serum albumin (Armour, England).

\section{Gel filtration}

Filtration on Sephadex G-75 gel (particle size 40 to $120 \mu \mathrm{m}$; Pharmacia, Sweden) was used for separation of trypsin inhibitor from rete testis fluid according to the manufacturer's instructions; fractions were eluted with trisHCl buffer $(5 \mathrm{~mm}, \mathrm{pH} 7 \cdot 5, \mathrm{NaCl} 0.15 \mathrm{~m})$ at a flow rate $0.1 \mathrm{ml} / \mathrm{cm}^{2}$. $\min$. The size of the column used was $1.4 \times 60 \mathrm{~cm}$ and the volume of fractions collected was $2 \cdot 3 \mathrm{ml}$.

For the determination of molecular weight, Blue Dextran (Pharmacia), bovine serum albumin (M.W. 67,000; Bayer, Germany) and L-tryptophan (M.W. 204; Hopkin \& Williams, England) were used as reference substances.

\section{Electrophoresis}

The electrophoretic separation of LDH isoenzymes in blood plasma, rete testis fluid and ram testis extract was carried out with agar gel (Agar noble special; Difco) as described by Wieme (1959). Before electrophoresis, rete testis fluid was concentrated by membrane ultrafiltration (Diaflo apparatus; Amicon N.V.) with UM-2 membrane to $1 / 10$ of the original volume. Samples of $10 \mu \mathrm{l}$ (BP) or $20 \mu \mathrm{l}$ (RTF and testis extract) were applied to filter paper strips and evaporated with a stream of cold air. The electrophoresis was performed at $+2^{\circ} \mathrm{C}$ for $3 \mathrm{hr}$ at $14 \mathrm{~V} / \mathrm{cm}$. The enzyme bands were visualized by the method of van der Helm, Zondag, Hartog \& van der Kooi (1962).

The electrophoresis and the detection of GOT isoenzymes were carried out with agar gel as described by Boyd (1962). Malate dehydrogenase isoenzymes were separated under the same conditions as GOT isoenzymes and they were 
demonstrated according to Thorne, Grossman \& Kaplan (1963). For separation of non-specific esterases, starch-gel electrophoresis was used as described by Smithies (1955). The electrophoresis was continued for $10 \mathrm{hr}$ at $10 \mathrm{~V} / \mathrm{cm}$. Enzyme bands were visualized with $\alpha$-naphthylacetate (Vanha-Perttula, 1966). The treatment and application of samples into gel was the same as described for $\mathrm{LDH}$ isoenzyme.

\section{RESULTS}

\section{Enzyme concentrations in ram rete testis fuid}

The only enzymes present in higher concentration in RTF than in blood plasma were those usually thought to be present in the acrosome and the kinoplasmic droplet, e.g. N-acetyl- $\beta$-glucosaminidase, acid phosphatase, arylsulphatase, and hyaluronidase (Hartree \& Srivastava, 1965; Dott, 1968; Dott \& Dingle, 1968); these differences were even more pronounced when the activity was expressed per unit of protein. However, the activities of the lysosomal enzymes were markedly reduced by high-speed centrifugation of RTF. This suggested that the enzymes were associated with particulate matter but the majority of spermatozoa still had their acrosomes and droplets attached as judged by phase-contrast microscopy.

All the non-lysosomal enzymes studied which are normally present in blood plasma were also present in rete testis fluid, but at a much lower concentration per unit volume. If allowance was made for the differences in protein concentration, enzyme activity per unit of total protein was similar in RTF and blood plasma for some enzymes studied, slightly higher in RTF for some and considerably higher for several enzymes, including MDH, GOT and alkaline phosphatase. There was no obvious relation between the molecular weight of the enzyme and the ratio between its concentrations in RTF and blood plasma. The activities of all the non-lysosomal enzymes were only slightly reduced by centrifuging RTF at $100,000 \mathrm{~g}$ for $1 \mathrm{hr}$ and this centrifugation also produced only a slight decrease in total protein concentration.

The RTF contained only low concentrations of those enzymes which were present in higher concentration in the testis than elsewhere in the body, e.g. $\mathrm{SDH}$ and the X-isoenzyme of LDH (Table 2 and Text-fig. 1). Indeed, the only isoenzyme of LDH demonstrable in RTF was isoenzyme 1 which is the most abundant of the five normally found in blood plasma. In the case of GOT and $\mathrm{MDH}$, however, RTF contained not only the cytoplasmic isoenzyme found in blood plasma but also the mitochondrial isoenzyme normally confined to tissues. The situation was further complicated for the various non-specific esterases. One of the esterases present in blood plasma also appeared in RTF, but RTF contained one and possibly two enzymes found neither in blood plasma nor in testis extracts. Most of the esterases found in testis extract could not be demonstrated in RTF (Text-fig. 1).

\section{Trypsin inhibitor in ram and boar $R T F$}

Rete testis fluid from both rams and boars contained an appreciable concentration of trypsin inhibitor, and an even higher concentration was found 


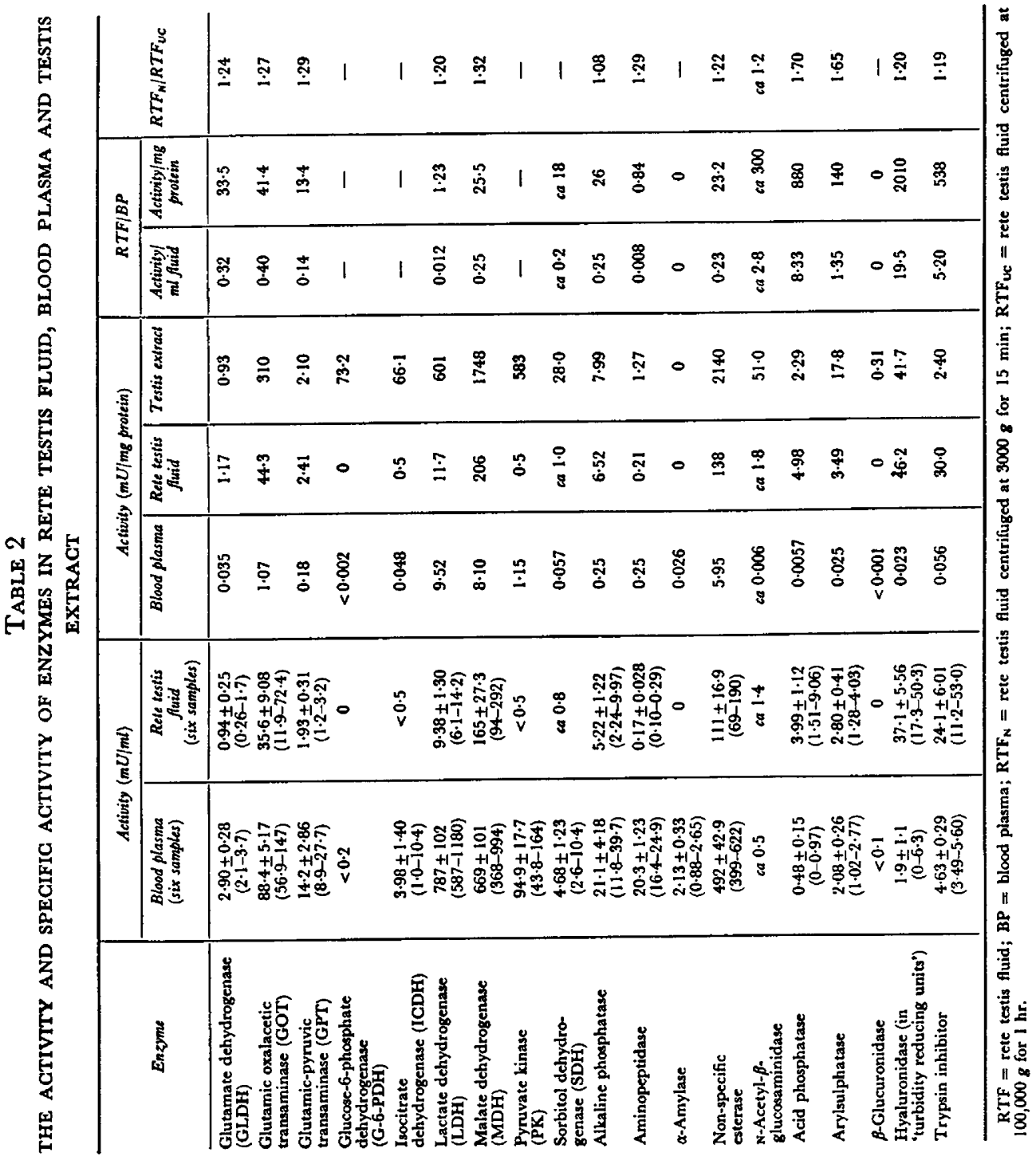


in the epididymal seminal plasma of both species. The concentrations in RTF were less than those found in seminal plasma (Table 3) but much higher than those in blood plasma. However, the specific activity (units of inhibitor/mg protein) was higher for RTF than for epididymal or seminal plasma in the ram. In the boar, the specific activity of the inhibitor was comparable in RTF and epididymal plasma, but both activities were about half the level found

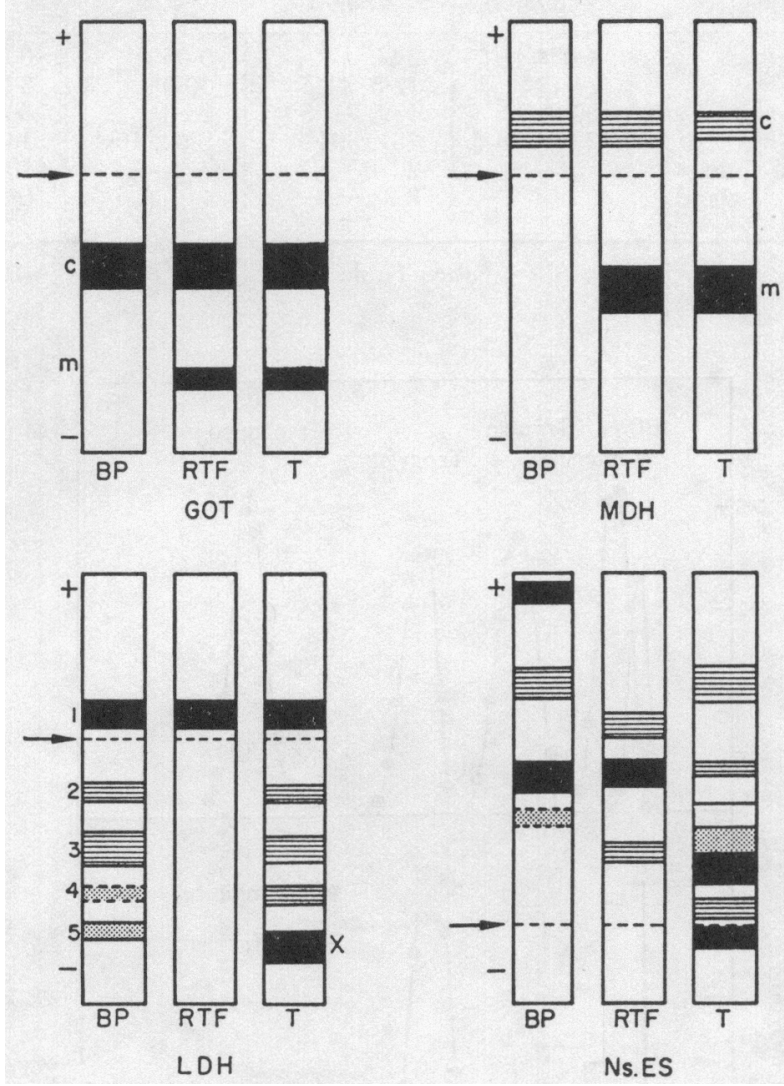

TExT-Fig. 1. Diagrammatic representation of the isoenzyme bands in blood plasma, rete testis fluid and testis extract (for abbreviations, see text). The arrow indicates the point of application of the sample. c: cytoplasmic isoenzyme; $\mathrm{m}$ : mitochondrial isoenzyme. $1,2,3,4,5$ and $X$ refer to the isoenzymes of $\mathrm{LDH}$ usually referred to in this way. More intense shading indicates a more intense staining of the gel.

in seminal plasma and very much less than that in seminal vesicle secretion. Cowper's gland secretion had negligible activity (Table 3 ).

The inhibitor could be separated on Sephadex G-75 from the majority of the protein and its retention volume was very similar to that of pancreatic trypsin inhibitor (Text-fig. 2), suggesting that its molecular weight was about 6500 .

\section{DISGUSSION}

These results indicate clearly that, in rams, indiscriminate transfer of enzyme 
TABLE 3

THE CONCENTRATION AND SPEGIFIC ACTIVITY OF A TRYPSIN INHIBITOR IN FLUIDS FROM THE REPRODUGTIVE TRAGTS OF RAMS AND BOARS

\begin{tabular}{l|l|l|l|l}
\hline & \multicolumn{4}{|c}{ Inhibitor concentrations } \\
\cline { 2 - 5 } & \multicolumn{2}{|c}{ Inhibitor $(m U / m l)$} & \multicolumn{1}{|c}{ Inhibitor (mU/mg protein) } \\
\cline { 2 - 5 } & Ram & Boar & Ram & \multicolumn{1}{c}{ Boar } \\
\hline Blood plasma & $4 \cdot 63^{*}$ & $2 \cdot 90$ & $0 \cdot 056^{*}$ & $0 \cdot 027$ \\
RTF & $24 \cdot 1^{*}$ & $12 \cdot 5,11 \cdot 6$ & $30 \cdot 0^{*}$ & $3 \cdot 81,6 \cdot 14$ \\
Epididymal plasma & 209 & $119,71,55$ & $23 \cdot 3$ & $6 \cdot 63,3 \cdot 28,2 \cdot 47$ \\
Seminal plasma & 250,239 & 231,394 & $8 \cdot 82,10 \cdot 4$ & $14 \cdot 0,10 \cdot 9$ \\
Fluid from seminal vesicles & - & 2870 & - & $18 \cdot 8$ \\
Fluid from Cowper's gland & - & $8 \cdot 92$ & - & $0 \cdot 18$ \\
\hline
\end{tabular}

* See Table 2.

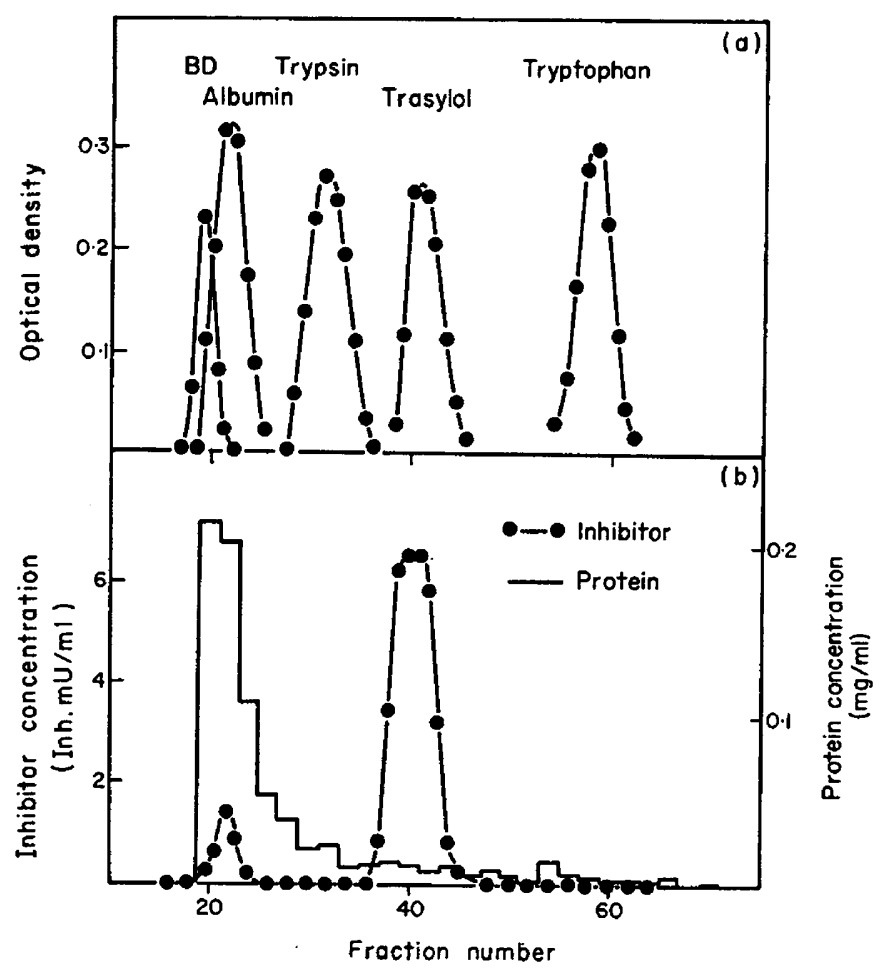

TEXT-FIG. 2. The separation of the trypsin inhibitor from rete testis fluid from the majority of the protein using a column of Sephadex G-75. Ram rete testis fluid was concentrated tenfold and $1.2 \mathrm{ml}$ was applied to the column. The upper part of the figure indicates the way various marker substances behaved on this column under these conditions.

protein from blood plasma or testis cells to rete testis fluid does not take place. The lysosomal enzymes which are found in the acrosome and cytoplasmic droplet (Dott, 1968) are in a special category as they are present in higher 
concentrations per unit volume of RTF than blood plasma and the activities can be markedly reduced by high-speed centrifugation. In this regard, these enzymes in RTF are similar to the analogous enzymes of semen (Dott \& Dingle, 1968) and this suggests that these enzymes arise from particles liberated from the epithelium at the time of sperm release or from fragments of detached acrosomes or droplets from the spermatozoa. Further evidence is needed before the origin and importance of these enzymes can be decided.

However, even when these lysosomal enzymes are excluded, there is no simple relation between the RTF to blood plasma activity ratios for the different enzymes and molecular size. Malate dehydrogenase, GOT and alkaline phosphatase all seem to be either selectively allowed through from blood plasma or are released into RTF by testicular cells. The latter appears to be the case with $\mathrm{MDH}$ and GOT from the high proportion of mitochondrial isoenzyme found in RTF.

The virtual absence of enzymes specifically associated with the testis was rather surprising, but adds support to the thesis that secretion of the fluid is largely independent of the germinal cells (Setchell, 1970) which appear to be the cells containing the specific enzymes (Bishop, 1968).

The presence of a high concentration of an inhibitor of trypsin in RTF of rams and boars and an even higher concentration in epididymal plasma has very considerable importance in our understanding of the mechanism of capacitation. A trypsin-like enzyme is associated in rabbits with the acrosomes of epididymal and ejaculated spermatozoa and is probably concerned in the penetration of the zona pellucida (Stambaugh \& Buckley, 1968). It has also been suggested that this enzyme is normally inhibited by a trypsin inhibitor in the seminal plasma (Zaneveld, Srivastava \& Williams, 1969, 1970). Although 'decapacitation factor' was also present in rabbit epididymal secretions (Weinman \& Williams, 1964; Robertson, 1969, quoted by Zaneveld et al., 1970 ) it was thought that most of the seminal inhibitor came from the accessory glands because of the much higher concentration of inhibitor in seminal vesicles than in the testis or epididymis (Haendle, 1968, quoted by Fritz, Fink, Meister \& Klein, 1970).

It is clear from our results that the concentrations of inhibitor in the semen of boars are much less than those in the seminal vesicle secretion. Despite their size, these glands contribute only about $20 \%$ of the ejaculate and the concentration of other substances specific to the seminal vesicles are also reduced by this proportion (Mann, 1964). The activity of the trypsin inhibitor appears to be reduced somewhat more than this, but the comparisons were not made on the same animals, and are therefore not entirely valid. However, the spermatozoa are not likely to come into contact with undiluted seminal vesicle secretion, so it is probably the concentration of inhibitor in ejaculated semen which should be considered, rather than that in the vesicular secretion.

The present results make it quite clear that ram and boar spermatozoa are exposed to a high concentration of trypsin inhibitor from the moment they leave the testis and probably from the time they are liberated from the germinal epithelium. Assuming that the inhibitor can enter the spermatozoa, the trypsinlike enzymes in the spermatozoa which facilitate penetration into many cell 
types as well as ova (Reid, 1965) would be inhibited until the spermatozoa are deposited in the female reproductive tract. Thus, the spermatozoa would be prevented from penetrating the cells lining the epididymis. Our evidence also supports the idea that dilution or removal of these inhibitors is an essential part of the process of capacitation. Decapacitation could also be easily explained by the return of inhibitors present in seminal plasma and it will be important to determine whether the inhibitors in rete testis fluid can also cause decapacitation.

\section{AGKNOWLEDGMENT}

We are grateful to Dr H. M. Dott and Dr C. Polge for supplying us with the ram and boar seminal plasma.

\section{REFERENGES}

BEDFord, J. M. (1970) Sperm capacitation and fertilization in mammals. Biol. Reprod., Suppl. 2, 128. Bessey, D. A., Lowry, O. H. \& BRock, M. J. (1946) A method for the rapid determination of alkaline phosphatase with five cubic millimeters of serum. F. biol. Chem. 164, 321.

Bishop, D. W. (1968) Testicular enzymes as fingerprints in the study of spermatogenesis. In: Reproduction and Sexual Behaviour, p. 261. Ed. M. Diamond. University Press, Indiana.

Boyd, J. W. (1962) Glutamate-oxaloacetate transaminase isoenzymes in rat serum. Clinica chim. Acta, $7,424$.

Di Ferrante, N. (1956) Turbidimetric measurement of acid mucopolysaccharides and hyaluronidase activity. 7. biol. Chem. 220, 303.

DotT, H. M. (1968) Lysosomes and lysosomal enzymes in the reproductive tract. In: Lysosomes in Biology and Pathology. Eds. J. T. Dingle and Honor B. Fell. North Holland Publishing Company, Amsterdam.

Dotr, H. M. \& Dingle, J. T. (1968) Distribution of lysosomal enzymes in the spermatozoa and cytoplasmic droplets of bull and ram. Expl Cell Res. 52, 523.

Findlay, J., LevVY, G. A. \& MARSH, G. A. (1958) Inhibition of glycosidases by aldonolactones of corresponding configuration. Inhibition of $\beta$-N-acetyl-glucosaminidase. Biochem. 7. 69, 467.

Fishman, W. H., Springer, B. \& Brunettr, R. (1948) Application of an improved glucuronidase assay method to the study of human $\beta$-glucuronidase. $\mathcal{F}$. biol. Chem. $173,449$.

FrTtz, H., Fink, E., Meister, R. \& KleIN, G. (1970) Isolierung von Trypsininhibitoren und TrypsinPlasmin-Inhibitoren aus den Samenblasen von Meerschweinchen. Hoppe-Seyler's Z. physiol. Chem. 351, 1344.

Fritz, H., Trautschold, I., Haendee, H. \& Werle, E. (1968) Ghemistry and biochemistry of proteinase inhibitors from mammalian tissues. Ann. N.Y. Acad. Sci. 146, 700.

Hartree, E. F. \& Srivastava, P. N. (1965) Chemical composition of the acrosomes of ram spermatozoa. F. Reprod. Fert. 9, 47.

Hopsu, V. K. \& Glenner, G. G. (1963) Further observations on histochemical esterase and amidase activities with similarities to trypsin. 7. Histochem. Cytochem. 11, 520.

Johnson, M. H. \& Setchell, B. P. (1968) Protein and immunoglobulin content of rete testis fluid of rams. F. Reprod. Fert. 17, 403.

Lowry, O. H., Rosebrough, N. J., Farr, A. L. \& Randall, R. J. (1951) Protein measurement with the Folin phenol reagent. $\mathcal{F}$. biol. Chem. 193, 265.

ManN, T. (1964) The biochemistry of semen and of the male reproductive tract. Methuen, London.

REID, B. L. (1965) The fate of isotope-labelled uterine spermatozoa in the mouse post coitum. Aust. 7 . Zool. 13, 525.

Roy, A. B. (1958) Comparative studies on the liver sulphatases. Biochem. 7. 68, 519.

Setchell, B. P. (1970) Testicular blood supply, lymphatic drainage and secretion of fluid. In: The Testis, Vol. 1, p. 101. Eds. A. D. Johnson, W. R. Gomes and N. L. VanDemark. Academic Press, New York.

SмгтніEs, O. (1955) Zone electrophoresis in starch gels: group variations in the serum proteins of normal human adults. Biochem. F. 61, 629.

Stambaugr, R. \& Buckley, Y. (1968) Zona pellucida dissolution enzymes of the rabbit sperm head. Science, N.Y. 161, 585 . 
Street, H. V. \& Close, J. R. (1956) Determination of amylase activity in biological fluids. Clinica chim. Acta, 1, 256.

Thorne, G. J. R., Grossman, L. I. \& Kaplan, N. O. (1963) Starch-gel electrophoresis of malate dehydrogenase. Biochim. biophys. Acta, 73, 193.

van der Helm, H. J., Zondag, H. A., Hartog, H. A. P. \& van der Kool, M. W. (1962) Lactic dehydrogenase isoenzymes in myocardial infarction. Clinica chim. Acta, 7, 540.

Vanha-Perttula, T. (1966) Esterases of the rat adenohypophysis. Acta physiol. scand. 69, Suppl. 283, 55.

Voglmayr, J. K., Scott, T. W., Setchell, B. P. \& Waites, G. M. H. (1967) Metabolism of testicular spermatozoa and characteristics of testicular fluid collected from conscious rams. F. Reprod. Fert. $14,87$.

Weinman, D. E. \& Williams, W. L. (1964) Mechanism of capacitation of rabbit spermatozoa. Nature, Lond. 203, 423.

WrEme, R. J. (1959) Application diagnostique de l'enzymo-électrophorèse des déhydrogenases de l'acide lactique. Clinica chim. Acta, 4, 46.

Zaneveld, L. J. D., Srivastva, P. N. \& Williams, W. L. (1969) Relationship of a trypsin-like enzyme in rabbit spermatozoa to capacitation. F. Reprod. Fert. 20, 337.

Zaneveld, J. J. D., Srivastava, P. N. \& Williams, W. L. (1970) Inhibition by seminal plasma of acrosomal enzymes in intact sperm. Proc. Soc. exp. Biol. Med. 133, 1172. 